\title{
Climate change clouds commercial licence to krill
}

Emma Marris

Marine biologists and government officials meet in Australia this week to agree on safeguards for Antarctic krill.

These pink crustaceans (Euphausia superba) darken the Southern Ocean in enormous swarms and underpin vital ecosystems. But according to evidence published in this issue (see page 100), melting ice in the region could compound the threat that the species already faces from commercial fishing.

$A$ research team, led by Angus Atkinson of the British Antarctic Survey, based in Cambridge, suggests that the krill population is declining with the retreat of winter sea ice in the region, which most scientists think is being driven by global climate change. In one region, the krill population has dropped by $80 \%$ over the past 30 years.

The Commission for the Conservation of Antarctic Marine Living Resources (CCAMLR), which was set up by the Antarctic Treaty and regulates the Southern Ocean's fisheries, began its annual meeting on 25 October in Hobart, Tasmania. The commission sets annual limits for krill, based on observations of the health and age of the population. But the commission's current monitoring system looks only at predators, not at long-term environmental change. Some marine biologists hope the research findings will change this.

Krill are caught mainly as food for domestic animals and fish, because they are fit for human consumption only when very fresh. The fishery is relatively small at the moment, but most observers expect that to change. Keith Reid, a marine ecologist at the British Antarctic Survey, predicts a "Klondike krill rush" as technology makes harvesting them easier and as other species are fished out. He hopes CCAMLR will be ready. "Here is a stock that has declined dramatically in the absence of fishing, but most models assume you have a stable population."

Denzil Miller, the executive secretary of CCAMLR, hopes to have a new monitoring framework in place within two years - in advance of any boom. Such a framework would take climate change into account, and divide the krill's range into small areas with individual caps to prevent overfishing of single sites.

"If there is a sudden explosion in the fisheries, we must have a framework to manage that," says Miller. "And we have to have these decisions pre-agreed."

\section{Early embryos fuel hopes for shortcut to stem-cell creation}

\section{Helen Pearson, New York}

In an advance that could boost the production of stem cells for medical research, fertility researchers have grown human embryonic stem cells from an embryo that was younger than any used before.

Yury Verlinsky and his colleagues at the Reproductive Genetics Institute in Chicago, Illinois, grew cells from four-day-old human embryos called morulae (see Reproductive BioMedicine Online www.rbmonline.com/ Article/1558). Previously, stem cells have been grown only from blastocyst-stage embryos, which are a day or two older and have more specialized tissues.

Researchers in the field say the new technique is quicker and simpler than previous methods and could boost the success rate for making embryonic stem-cell lines, which are in short supply. "It takes a huge step out of the whole process," says Peter Braude, who studies human embryonic stem cells at Guy's, King's and St Thomas' School of Medicine in London.

Verlinsky and his team attempted to grow stem cells from 46 human morulae left over from in vitro fertilization (IVF) treatment. They succeeded in making eight stem-cell lines - a success rate roughly equivalent to that achieved using blastocysts.

In its paper, the team presents preliminary evidence that these stem cells are able to generate a similar repertoire of cell types to those grown from blastocysts. They have already used both techniques to create a library of stem-cell lines for disease research, including many carrying genetic abnormalities (see Nature 429, 691; 2004).

The new method is advantageous because it avoids the delicate task of culturing embryos until they grow into blastocysts, a period when perhaps half of them stop growing or die. It also cuts out a laborious step from the conventional technique, in which the outer shell of the blastocyst is destroyed to gain access to the precious 20-30 stem cells inside. In the new method, the entire morula of around 60-70 cells is grown in culture.

The advance is unlikely to affect the contentious global debate over the ethics of embryonic stem-cell research, scientists say. Opponents of such research point to the fact that stem-cell lines can only be created by destroying a human embryo.

But Braude notes that researchers will now want to test the more radical concept of growing stem cells from a single cell plucked from a morula-stage embryo without damaging the rest of it. That would also raise the prospect that couples having IVF treatment could ask to have one of their embryo's cells removed before it is implanted in the womb. The cell could be grown into a stem-cell line and stored in case the child should need it for disease therapy in the future.

Because this technique would avoid destroying the entire embryo, stem-cell researchers say that it could also serve to quell some of the ethical arguments against the use of human embryos for research.

Researchers might also use the new method to grow stem cells from morulastage embryos that have stalled in their development and are incapable of growing into babies, suggests stem-cell researcher Jose Cibelli of Michigan State University in East Lansing. "You could remove a big obstacle from the ethical standpoint," he says.

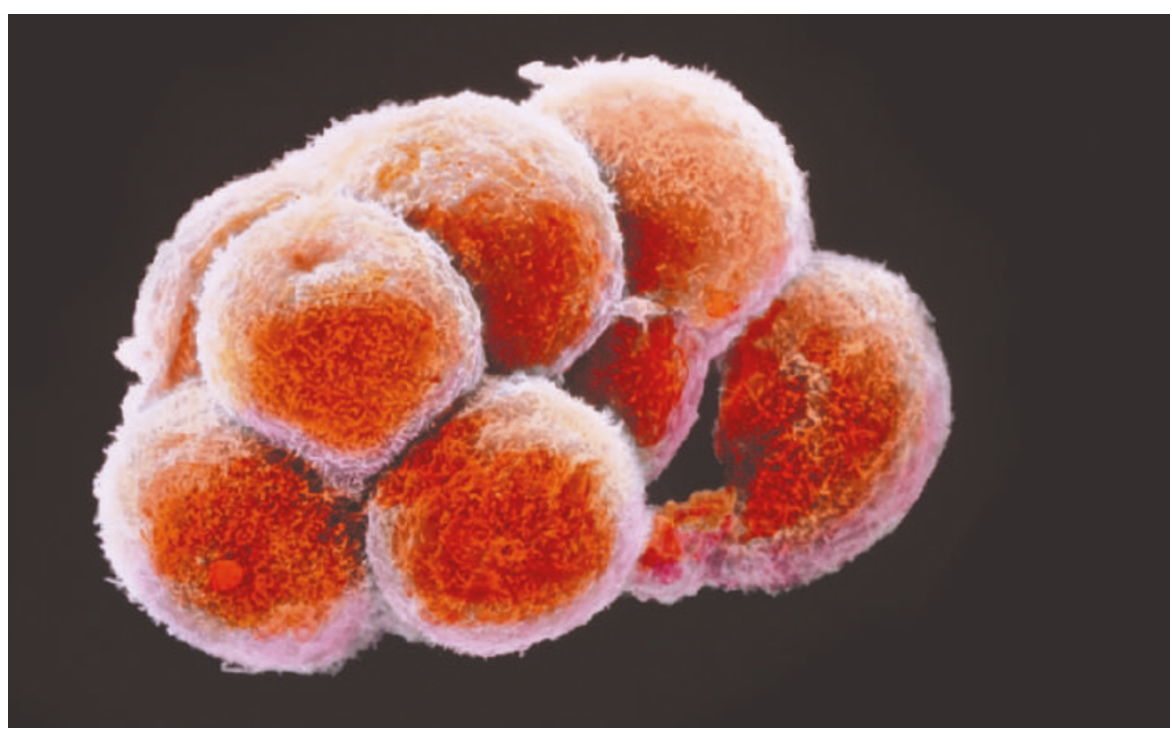

More from morulae: stem-cell lines have been created from embryos consisting of very few cells. 